\title{
Strategi Guru PAI Mengatasi Kesulitan siswa Dalam Membaca Al-Qur'an Melalui metode pembiasaan di SMK Al Kholily Mlokorejo Puger Jember
}

Tahun Pelajaran 2018/2019

\author{
Badrut Tamami \\ Universitas Muhammadiyah Jember \\ Email : badruttamami@unmuhjember.ac.id
}

\section{Submission}

Track:

Received:

6 Agustud 2020

Final Revision:

1 Sepetember 2020

Available online:

25 September 2020

Corresponding

Author:

Name \& E-mail Address

Badrut Tamami

badruttamami@,unmuhjember.ac.id

\section{ABSTRACT}

Education is an important factor which cannot be segregated from the life of all human beings, both individually and collectively. Strategies employed by the teacher of PAI (Islamic education) thus have an important role in establishing students' personality, especially with regard to their religious character. The teaching of $P A I$ therefore must be performed gradually and continuously. Students' ability in reading Qur'an must be improved significantly. A method of habituation constitutes one that can be used to improve students' ability in reading Qur'an. The problems in this research are as follows: 1. How did a PAI teacher overcome problems and difficulties in reading Qur'an through the use of a habituation method at SMK Al Kholily Mlokorejo Puger Jember?; 2. What were inhibiting factors and what were the solutions? This study employed a qualitative approach in the form of a case study. Data were colleted by ways of observation and interviews. The respondents were students at SMK Al Kholily Mlokorejo Puger Jember. The results revealed that the difficulties in reading Qur'an can be improved through the use of a habituation method.

Keywords : Strategi, Al-Qur'an, habituation method

\section{PENDAHULUAN}

Pada hakikatnya Pendidikan Islam merupakan sebuah proses perubahan yang menuju kepada arah positif, sejak zaman Nabi Muhammad SAW konsep pendidikan adalah sejarah perubahan positif yang merupakan jalan tuhan untuk dilaksanakan. dalam konsep perubahan yang lebih baik Pendidikan islam diidentikkan dengan ajaran dakwah untuk menyampaikan wahyu pertama yaitu iqro (membaca) kepada ummat.
Nilai ilahiyyah dalam Ilmu Peindidikan isllam dapat juga didefinisikan untuk mengkaji ideologi isllam tentang karakter pendidikan yang menafsirkan fenomena alam dan social. Secara simple kaidah pendidikan islam bukanlah sekedar tentang teeori ilmu pendidikan, atau dalil Al-Qur'an dan hadits yang diinterpretasikan dan dikaitkan pada dunia pendidikan, melainkan sebagai bentuk ilmu yang didalamnya memuat konsep teori pendidikan yang proporsional yang disesuaikan dengan berdasarkan kitab suci. 
Pendidikan Islam merupakan ilmu yang disandarkan kepada agama islam, di implementasikan oleh nabi Muhammad SAW yang disisipkan tentang kegiatan kehidupan manusia, dirumuskan berdasarkan Teks AlQur'an dan Hadits serta akal manusia, oleh karenanya ilmu pendidikan islam merupakan ilmu yang diberikan Oleh Allah SWT melalui ayat Al-Qur'an dan Hadits juga sebuah akal (pemikiran). apabila terdapat ketidak jelasan karena memang Al-Qur'an bersifat global, maka harus didapati dan di pelajari di dalam Hadits Nabi. dan kemudian menggunakan akal (pemikiran) jika terjadi ketidakjelasan dengan syarat akal tidak boleh bertentangan dengan sumber hokum utama yaitu Al-Qur'anul karim dan Hadits (Ahmad Tafsir, 2014:12).

Peran seorang guru dalam konsep agama islam adalah mendidik, dalam artian menjalankan tugas belajar mengajar haruslah di berikan nilai-nilai mendasar keteladanan, dan juga memberikan sebuah motivasi, evaluasi, pujian, hukuman, serta membiasakan dengan hal- hal yang baik, disinilah tugas dan peran serta tanggung jawab guru sangatlah signifikan, seperti halnya strategi guru agama dalam mengatasi kesulitannya untuk membaca AlQur'an pada siswa SMK Al-Kholily Mlokorejo Puger jember. Strategi dan kreatifitas guru sangat berpengaruh dalam hal mengajarkan serta mendidik tentang membaca dan menulis Al-Qur'anul karim pada siswa dengan membantunya untuk membaca Al-Qur'an dengan metode buku Iqra misalnya untuk dijadikan media pembelajaran.
Guru selain sebagai seorang pendidik juga berperan seyogyanya menjadi orang tua, sehingga profesi guru memiliki pengaruh sangat penting di dalam pembentukan kecerdasan dan kepribadian siswa. Problematika yang ada pada saat ini yaitu sedikitnya waktu dalam proses belajar mengajar,ditambah individu siswa yang mempunyai kemampuan pedagogik yang berbeda sehingga akan menghasilkan perbedaan outcome. Disinilah Strategi dan upaya guru diharapkan agar supaya bisa membantu untuk mengatasi permasalahan dan kesulitan siswa dalam membaca Al-Qur'an.

Pengaruh pendidikan yang dialami oleh anak tidak hanya diperolehb dari seorang guru, melainkan pendidikan karakter dari orang tua sangatlah signifikan dalam membentuk intelektual kognitif siswa, akan tetapi masih banyak orang tua yang tidak mempunyai waktu untuk putranya sehingga pendidikan anaknya kurang maksimal, mereka hanya bisa menyekolahkan anak sesuai dengan kemauan dan keinginan anak tanpa perlu repot mendidiknya lagi.

Berdsarkan hasil pengamatan, studi kasus di SMK Al Kholily Mlokorejo Puger sangat sesuai untuk dijadikan sarana tentang melatih bacaan Al-Qur'an siswa selama disekolah tersebut, banyak siswa yang kesulitan untuk membaca Al-Qur'anul karim pada usia yang seharusnya siswa sudah bisa dan fasih huruf dasar atau Hijaiyah yang merupakan materi dasar untuk mempelajari Al-Qur'an.

HASIL dan PEMBAHASAN 


\section{Guru}

Definisi guru secara sederhana adalah seseorang yang mentransferkan ilmu pengetahuannya kepada peserta didik (Saiful, 2000). Guru merupakan komponen paling penting di dalam proses pendidikan. tugas dan tangung jawabnya sangat besar untuk bisa mewujudkan anak didik menjadi sukses dan berhasil kearah tujuan yang di cita-citakan.( Suhartoe, 2006).

Dalam pandangan masyrakat kita, guru adalah seorang yang dinilai bisa melaksanakan proses belajar mengajar baik dikelas formal mauun non formal, karena mereka menganggap guru merupakan suatu panutan bagi mereka tempat anak mereka bisa di ajarkan hal-hal yang baik dan mendapatkan pengetahuan yang baru. masyaraakat sangat yakin bahwasanya guru lah orang dianggap mampu untuk mendidik anak hingga dia mempunyai tingkah laku dan berkepribadian yang baik.

Agama Islam sangatlah menghargai kepada orang yang berilmu (ulama dan guru), sehingga merekalah yang mencapai derajad yang tinggi dan keutuhan hidup, di dalam surat Al- Mujadalah ayat ke-11 Allah SWT berfirman :

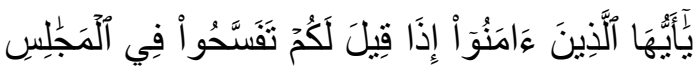

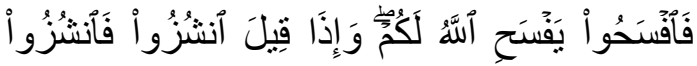

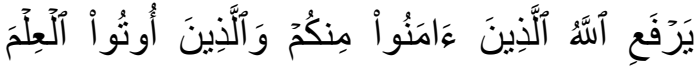

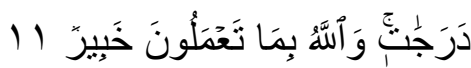

Artinya : Hai orang-orang beriman apabila dikatakan kepadamu: "Berlapanglapanglah dalam majlis", maka lapangkanlah niscaya Allah akan memberi kelapangan untukmu. Dan apabila dikatakan: "Berdirilah kamu", maka berdirilah, niscaya Allah akan meninggikan orang-orang yang beriman di antaramu dan orang-orang yang diberi ilmu pengetahuan beberapa derajat. Dan Allah Maha Mengetahui apa yang kamu kerjakan (Depag-RI, 2003).

Definisi upaya yaitu suatu ihtiar atau usaha yang dilakukan yang bertujuan untuk mencari solusi atau pemecahan masalah. Upaya terkait dengan hal ini yaitu mencari cara untuk mengatasi siswa yang mengalami kesulitan membaca Al Qur'ean.( kbbi.web.id) Dalam hal ini upaya guru sebagai pendidikan agama Islam di harapkan mampu dalam mewujudkan apa yang ingin dituju untuk keberhasilan dalam pembelajaran siswa khusunya dalam pendidikan membaca $\mathrm{Al}$ Qur"an, diantaranya upaya guru sebagai berikut :

1) Guru sebagai penentu keputusan

keputasan dalam pemilhan media pembelajaran dan bahan ajar merupakan persiapan dab strategi Guru, banyak sekali metode yang dilakukan dalam pemilihan proses pembelajaran diantaranya jigsaw, ceramah, tugas presentasi dan lain sebagainya,maka keputusan inilah diajarkan kepada siswa dengan mengedepankan kemampuan murid dalam menyerap materi, apa yang di perlukannya dan apa yang ingin dicapai.

2) Guru seebagai manager

Dalam berinteraksi antara guru dengan siswa waktu yang digunakan secara 
verbal antara 20-30 persen setiap harinya. Sedangkan selebih nya dipergunakan untuk menyusun kegiatan dan pengelolaan yang meliputi organisasi pembelajaran. pengisian formulir administrasi, melaksanakan ujian, mengawasi pekerjaan rumah siswa, serta menyiapkan dokumen dan menghadiri rapat penting.

Kemudian bentuk lainnya adalah kegiatan pengelolaan kelas, misal kegiatan yang membutuhkan penanganan dan keputusan, tindakan yang kiranya diperlukan untuk pembinaan ketertiban di kelas. Hal ini seharusnya menjadi perhatian semua stake holder bukan hanya sebatas pengawasan guru.

3) Guru sebagai konseling

Guru selain mendidik dituntut untuk menjadi seorang konselor yang peka dan tanggap terhadap prilaku dan aktifitas keseharian muridnya. Seorang Guru juga harus bisa memberikan masukan yang konstruktif kepada murid yang mengalami ketidak percayaan diri dalam belajar.oleh karenanya modal awal seorang pengajar haruslah menguasai ilmu psikologi kejiwaan.

karena mereka harus bisa apabila muridnya memerlukan konsultasi kepada psikologi mental misalnya. Dikarenakan tiap murid kadang kala mengalami kesulitan dalam menganalisa dan mengutarakan permasalahn yang dialaminya, sehingga mereka jarang mengadukan setiap permasalah pribadinya kepada guru.

Selain itu guru juga harus mempunyai kreatifitas dan seni dalam mengajar di kelas. Guru harus bisa membuat suasana yang menyenangkan di dalam kelas, serta mereka harus bisa membuat muridnya menjadi nyaman untuk berada didekat mereka untuk sekedar menyampaikan curahan hatinya.

4) Guru sebagai tauladan

Guru yang kadang diartikan juga untuk di gugu dan ditiru mempunyai pengaruh sebagai tauladan atau contoh bagi muridnya. semangat siswa terhadap s mata pelajaran juga dipengaruhi oleh bagaimana guru tersebut menyampaikan materi dengan berbagai macam strategi yang sesuai dengan kemampuan siswa.agar supaya siswa mampu menyerap teori dengan seratus persen dan juga dengan senang dan bahagia.

Berdasarkan penjelasan tersebut, guru harus menyadari bahwasanya usahanya sebagai tauladan dan contoh selalu berpengaruh terhadap pola pikir siswa yang akan meniru dan mengadopsi sebagai modul cara berfikir untuk menyelesaikan masalah secara teoritis.

5) Guru sebagai pengawasan dan korektor guru bertindak sebagai pengawasan dan korektor sebisa mungkin untuk membedakan antara nilai yang baik dan buruk. keduanya harus dipahami dalam kultur kehidupan masyarakat. Basic dan proses kehidupan anak didik terkadang berbeda-beda sesuai dengan adat budaya dan kualitas sumber daya masyarakat di mana siswa tinggal yang akan mempengaruhi proses pola piker dan intelektual kecerdasan siswa.

\section{Pendidikan Agama Islam}

Pendidikan merupakan proses usaha sadar dan terencana dalam menciptakan 
kondisi pembelajaran secara aktif untuk mengembangkan potensi individu siswa agar supaya mempunyai kekuatan religiusitas dan spiritual keagamaan, kecerdasaan, pengendalian diri, ahlak mulia, keterampilan, serta kepribadian yang diperlukan pada individu seseorang, masyarakat, bangsa dan negaranya ( Syukur, 2004).

Pendidikan agama Islam pondasi ketaqwaan generasi terdahulu untuk diwariskan kepada para siswa agar semakin baik dan bertambah etika, pengetahuan, pengalaman, keterampilan , kecakapan, dan kelak menjadi insan muslim yang beriman, berbudi pekerti luhur, bertaqwa kepada Allah SWT dan berkepribadian yang islami serta memahami, dan mengimplementasikan ajaran agama Islam dalam kehidupannya.

Pada hakikatnya pendidikan agama Islam merupakan suatu proses perubahan prilaku dan akhlak seseorang menuju sikap yang lebih baik. sejak zaman Nabi Muhammad SAW pada ilmu tarikh kesejarahan, perubahan yang positif ini merupakan hidayah Tuhan kepada manusia yang telah di implementasikan dalm kehidupan sehari-hari.

Ketika wahyu yang pertama kali diturunkan dengan kalimat Iqro' (bacalah), pendidikan agama Islam secara otomatis dan praktis telah dimulai, penuh dengan pemahaman dan penghayatan, dan eksis dalam nilai-nilai kehidupan umat Islam, berdasarkan sebuah proses transfer knowledge yang melibatkan Tuhan.

Pendidikan Islam merupakan pusat ilmu yang didasarkan kepada nilai keIslaman. Islam adalah re presentasi dari agama yang diajarkan oleh Nabi Muhammad SAW. berisi tentang seperangkat pendidikan tentang pola berbagai manusia, ajaran itu di landasi atas dasar sumber $\mathrm{Al}$ Qur an dan hadits serta akal. (Tafsir , 2014).

Di sekolah baik formal maupun non formal pendidikan agama Islam sebagai Mata pelajaran yang secara menyeluruh mengajarkan berdasar Al Qur"an dan hadits, dengan lingkup keimanan fiqh/ibadah dan sejarah, sekaligus mencerminkan bahwa pai mencakup nilai-nilai keseimbagan dan keselarasan antara manusia dengan sang penciptanya, individu, serta lingkungannya.

Ada dua faktor yang perlu di perhatikan dalam kegiatan pembelajaran pendidikan agama Islam yaitu sebagai berikut: a. siswa yang akan dipersiapkan untuk sampai pada tujuan, dalam artian perlu intensif pembimbingan, menumbuhkan rasa percaya diri sebagai bentuk peningkatan keyakinan dan keimanan, pengalaman, penghayatan, pemahaman, terhadap ajaran agama Islam.

b. Guru PAI yang telah melaksanakan suatu bimbingan secara intensif, dan memberikan pelatihan secara sadar terhadap siswanya untuk meningkatkan kualitas diri serta membentuk kesalehan pribadi, juga sekaligus membentuk kesahlehan sosial.( Muhaimin : 76 ) .

Berdasarkan beberapa keterangan diatas dapat disimpulkan bahwa PAI merupakan wujud usaha sadar bersama yang dilakukan semua unsure baik pendidik 
maupun peserta didik dalam rangka menyiapkan siswa dalam meningkatkan keimanan dan keyakinan, serta pengalaman, pemahaman, terhadap ajaran agama Islam yang di sesuaikan dengan tujuan bersama yang ingin dicapai.

\section{Kesulitan dalam Membaca Al Qur'an}

Dalam berinteraksi manusia dengan sesama membutuhkan sebuah pemahaman bahasa baik itu verbal maupun tulisan, dalam memaknai suatu tulisan sebagai bentuk komunikasi antara penulis dengan pembaca .terdapat tiga unsure yang harus dipahami, yaitu makna sebagai isi dari bacaan, kata sebagai unsur penjelasan makna, dan tulisan sebagai objek visual.

Lebih dalam lagi terdapat kajian yang lebih spesifik tentang makna, membaca merupakan kegiatan melafalkan sekaligus pemahaman makna dengan baik dan benar, yang mengedepankan nilai kognitif dan psikomotorik, melainkan lebih dari sekedar itu juga terkait penjiwaan untuk memahami isi bacaannya. (Hermawan, 20113).

beberapa tahap dalam pengembangan membaca antara lain yaitu persiapan, karena merupakan bagian awal permulaan, dan sebuah keterampilan membaca dengan cepat, wawasan luas. bagi Anak yang mengalami kesulitan dalam membaca dikarenakam kebiasaan mereka membaca yang tidak benar.

Tanda Mereka sering membaca dengan tidak benar yaitu dengan memperlihatkan adanya gerakan dan pemikiran yang selalu menunjukkan ketengangan seperti halnya, sering gelisah, intonasi suara tinggi, adakalanya mengigit bibir, sering kali mereka juga bersikap merasa tidak aman dengan takut disuruh untuk menyelesaikan soal di depan kelas oleh gurunya.

Menanamkan rasa cinta Al Qur an di hati anak termasuk tugas yang sulit. Salah satu sarana penujangn yang dapat mempermudah pendidik dalam menunaikan tugas ini adalah dengan mengunakan berbagai media pembelajaran yang bervariasi dan berusaha untuk terus memperbarui metode pengajaran yang sesuai dengan peserta didik. Menginovasikan sebuah pembelajaran yang dilakukan oleh seorang guru harus bisa membuat peserta didik nyaman dan memgerti metode yang akan digunakan dalam membantu siswanya untuk belajar Al Qur ${ }^{\text {ee an, }}$ yang seharusnya menyesuaikan kepribadian pada siswa.

\section{Problematika Belajar}

Belajar adalah intisari dari permasalahan pengajaran dan pendidikan, karena kegiatan utama dari belajar pendidikan dan pengajaran. Merupakan upaya guru agar siswa diarahkan belajar, karena dengan belajar siswa dapat berkembang sesuai dengan potensi yang dimilikinya. Semangat siswa dalam belajar tidak jarang mendapatkan hasil yang diharapkannya. Adakala siswa mengalami kendala dan kesulitan yang diimplementasikan dalam suatu penyebab adanya masalah. Dalam Setiap indikasi permasalahan ada yang melatar belakanginya,

pada dasarnya kegiatan Belajar adalah aktifitas usaha aktif seorang untuk 
mendapatkan suatu pengalaman dan pengetahuan yang baru, sehingga terbentuklah pola pikir baru menuju kearah yang lebih baik. akan tetapi realitanya para siswa sering kali tidak mendapatkan perubahan pola piker dan tingkah laku seperti yang dicita citakaan. Oleh karena itu menimbulkan persepsi bahwa pelajar mengalami kendala dan kesulitan dalam belajar yang merupakan sebuah hambatan untuk mencapai hasil pembelajaran yang maksimal.

Beberapa faktor kriteria untuk mengetahui siswa yang sedang mengalami kesulitan dalam proses belajar:

a. Murid bisa dikatakan gagal apabila, jika dalam waktu yang ditentukan tidak dapat mencapai standart mutu, sebagai tolak ukur keberhasilan atau tingkat pemahaman minimal mata pelajaran tertentu yang telah di tetapkan dan disepakati oleh orang tua dan guru.

b. Siswa dapat dikatakan tidak berhasil jika dalam waktu yang ditentukan tidak bisa mencapai prestasi yang diharapkan sebagaimana semestinya.

c. Siswa tidak dapat mengerjakan tugas yang diberikan oleh guru sebagai pemacu perkembangan, kognitif dan psikomotoriknya untuk menyesuaikan dengan kondisi sosial lingkungannya.

d. Siswa tidak dapat untuk mencapai great atau tingkat selanjutnya yaitu penguasaan dan pemahaman yang diperlukan sebagai salah satu pra syarat untuk kelanjutan proses belajarnya.

Cara untuk mengatasi beberapa kesulitan dalam belajar yang dialami oleh siswa, hendaknya guru harus mengetahui kendala dan hambatan dalam proses belajar yaitu:

a. Mengetahui cara belajar yang efektif, Sebenarnya dalam proses belajar terdapat kiat yang perlu diketahui oleh siswa, yaitu dengan cara belajar yang teratur dan terus menerus, meskipun dalam waktu yang relative singkat, dan siswa diajarkan bagaimana cara berfikir yang sistematis sehingga dalam penyerapan materi siswa tidak berputar-putar dengan banyaknya materi yang disampaikan dan harus dikuasainya. Sehingga waktu yang tidak terbuang dengan percuma dan efektif serta menyenangkan.

b. hilang minat belajar, Dalam proses belajar, minat menjadi faktor yang paling utama, karena siswa dapat lebih semangat belajarnya. Minat bisa dipengaruhi dari factor eksternal contohnya lingkungan keluarga, teman bermain, dan factor internal yaitu dari dalam dirinya sendiri seperti keinginan untuk menjadi bisa,mempunyai cita-cita yang bisa dijadikan motivasi bagi dirinya sendiri.

c. Hilang Konsentrasi, dalam memulai proses belajar harusnya siswa di persiapkan betul mengenai kesiapannya agar supaya mereka bisa fokus dan konsentrasi. Karena hal tersebut sangat mempengaruhi terkait pemahaman dan penguasaan materi belajar. Yang sering terjadi belum siapnya mental anak karena masih dalam proses peralihan dari suasana bermain yang menyenangkan ke suasana 
belajar yang membosankan. Tidak sedikit pula proses belajar berhenti dikarenakan anak gagal pada fase transisi tersebut. Oleh karena itu kehilangan focus dan konsentrasi pada saat belajar bisa dikatakan sangatlah mengganggu, lebih lagi pada saat musim ujian tiba.

d. Stress terhadap anak, Perlu juga diperhatikan persiapan mental dan psikologi anak dalam belajar, karena bisa mempengaruhi gangguan piker terhadap anak atau stress yang dapat mengenai siapapun dan kapanpun. Baik anak-anak maupun orang dewasa. Terlalu di forsir dan mendapatkan tekanan juga salah satu penyebab datangnya strees pada seseorang, yang akan sulit untuk bisa berkonsentrasi pada proses belajar. Adanya tuntutan dari orsng tua dan guru yang terlalu tinggi kepada murid,untuk selalu berprestasi yang bisa membebani mental dan psikologi anak. Akhirnya banyak dari mereka justru malas untuk belajar dikarenakan terlalu dibebani oleh tuntutan.

e. Belajar saat menjelang ujian, mayoritas kesalahan pada anak dalam system belajar yaitu mereka menganggap belajar hanya untuk menyelesaikan soal ujian saja, bukan untuk mendapatkan pengetahuan dan wawasan yang baru, hanya terbatas dengan jangka pendek dalam masa ujian dan bisa mengerjakan soal.

\section{Faktor pengaruh Belajar}

Dalam menumbuhkan rasa semangat belajar seseorang di pengaruhi beberapa factor, diantaranya yaitu ;

a. Faktor internal individu, factor internal individu juga menyangkut tentang jasmani dan rohani, jasmani lebih kepada kesehatan fisik jasmani. Kondisi dan stamina fisik individu sangatlah berpengaruh sekali, salah satu contoh adalah belajar selama berjam-jam masih bisa focus dan konsentrasi, akan tetapi ada juga yang hanya bertahan 1 sampai dengan 2 jam bahkan beberapa menit dalam belajar. Aspek mental psikis juga mempengaruhi dalam proses belajar, faktor psikis lebih kepada kondisi kesehatan mental berupa kemampuan dan keterbatasan daya serap, keseimbangan emosi, frustasi, tekanan pada batin, dan merasa tidak nyaman pada suasana belajar serta hilangnya konsentrasi. Faktor kejiwaan dan mental psikis tersebut sangatlah besar pengaruhnya untuk kegiatan proses belajar mengajar Pendidikan Agama Islam secara langsung di sekolah yang mempunyai berlatar belakang non muslim. Metode pelajaran PAI menjadi lebih sulit bagi para siswa dan guru PAI itu sendiri. dan dampaknya pada kehidupan sosial terutama pada system yang berlaku di sekolah. Tingkat kecerdasan intelektual merupakan bagian dari bakat juga penguasaan oleh siswa tentang materi pelajaran. faktor sosial meliputi (lingkungan, sekolah, orang tua, suasana rumah) semuanya merupakan factor yang berhubungan dengan siswa, teman, guru, maupun orang tua dan orang 
yang berada di sekitarnya.

b. Faktor lingkungan, factor lingkungan merupakan factor penunjang Keberhasilan proses belajar dari unsur eksternal dari luar diri siswa, dari aspek luar pengaruhnya sangat besarkarena aktivitas pembentukan mental dan semangat siswa baik dari factor fisik masupun social psikologi jasmani dan rohani sangat signifikan.

Secara mayoritas keseluruhan, aspek yang dapat mempengaruhi sisi negatif terhadap perkembangan mental anak terhadap pendidikan agama islam yaitu:

a) Unsur di Sekolah: SMK Al kholily merupakan SMK yang ada di desa Mlokorejo Puger yang berbasis pada ketrampilan berwirausaha dan teknologi,dan kurangnya jam mata pelajaran Pendidikan Agama Islam sehingga anak focus hanya berwira usaha.

b) Unsur Orang Tua: padatnya aktifitas dan kesibukan orang tua sehingga memberikan perhatian kepada anak menjadi berkurang, dan minimnya berinteraksi dengan anak menjadikan anak enggan untuk menyampaikan permasalahan yang dihadapinya.

c) Suasana kondisi rumah: seringnya terjadi kegaduhan dalam rumah, suasana yang sangat tegang, dan kurang menjaga kebersihan lingkungan rumah.

d) Factor ekonomi : stabilitas ekonomi kedua orang tua sangat berpengaruh, karena merupakan dasar dari kebutuhan anak yang menjadi fasilitas dalam kebutuhan dan pemenuhan penunjang belajar.

e) Lingkungan Masyarakat: teman sepermainan. media sosil, , lingkungan sekitar rumah, dan pola berkehidupan dengan tetangga.

f). Lingkungan Sekolah: baik dari aspek metode pembelajaran/ kurikulum, kelengkapan sarana dan prasarana, kualitas SDM tenaga pengajar, manajemen strategi kepemimpinan kepala sekolah merupakan factor penunjang dalam mempengaruhi dampak positif dalam memudahkan siswa untuk mudah dalam belajar.

Tugas dan kwajiban guru agama adalah salah satunya untuk mengatasi kesulitan siswa dalam belajar Al-qur'an yaitu sebagai seorang pembimbing. Dalam memberikan bimbingan seorang guru Pendidikan Agama Islam haruslah meliputi aspek bimbingan proses belajar serta bimbingan terhadap perkembangan sikap religious dan keagamaan siswa.

Berdasarkan fakta tersebut, pembimbingan dan memberikan arahan yang dimaksud adalah agar setiap individu anak bisa berubah dalam hal mengenai kemampuan pada diri anak dan potensi dalam diri yang dalam kapasitas proses belajar dan menyikapi sebuah permasalahan yang dialaminya.

\section{KESIMPULAN}

a. Kemampuan belajar siswa yang lemah, Salah satu cara dalam mengatasinya adalah dengan memberikan motivasi dan reward untuk memacu semangat belajarnya, menumbuhkan rasa percaya diri kepada 
siswa sehingga mereka dapat yakin bisa untuk mempelajari materi,dan selalu memberikan wawasan dan pengalam yang luas dan menarik sehingga siswa tertarik dan tidak bosan untuk selalu belajar. Di sekolah siswa di berikan Modul cara menguasai suatu materi dengan mudah yang merupakan satuan kurikulum dengan untuk ditujukan kepada siswa agar lebih mudah dalam memahami dan bisa dipelajari dimanapun, tugas guru hanya memberikan penjelasan dan keterangan dikala siswa bmengalami kesulitan dalam memahaminya.

b. lambat memahami, Beberapa cara yang dapat membantu siswa yang mengalami lambat dalam memahami sebuah materi dalam proses belajar, antara lain yaitu :

1) Memberikan perhatian yang lebih intens dan khusus secara individual, misalnya: dengan dukungan alat peraga sebagai pengganti dari pemberian keterangan dan lain sebagainya.

2) Memberikan waktu dan kesempatan yang lebih lama untuk belajar kembali dalam menguasai materi yang sudah dipelajarinya berulang- ulang.

3) Meminta bantuan teman sebaya yang sudah akrab dan terbiasa berdialog berkomunikasi dengan siswa yang mengalami keterlambatan dalam belajar.sehingga bisa mengetahui kendala yang dialami siswa tersebut.

4) Meringkas dan merangkum materi yang akan diberikan sehingga menjadi sederhana dan lebih mudah siswa dalam memahaminya.

5) Membiasakan bekerja sama dan saling membantu antara teman dikala ada yang mengalami kesulitan dalam memahami materi dalam artian bukan mencontek waktu mengerjakan soal melainkan dalam memahami penguasaan materi belajar.

\section{DAFTAR PUSTAKA}

Abdurrahman, Molyuno, 2012., kesulitan Belajar Anak, Jakarta.

Anounim, 2017, Httpss/Kbbi.Web.Id/ 19 Agustus 2019. Jam 22.11 WIB

Darnyantoe,Rahardjo. 2012, Model Pembelajaran yang Inovatif, Yogyakarta.

Griya Media Departemen agama RI, 2003. AlQuran dan Terjemahnya. Jakarta.

Daradjat, Zakyah. 2011,. Ilmu Pnddikan Islam.Jakarta. Bumi Askara.

Rahman, Abdul, 2000. cara Mendidik Anak. Bandung:

Soelaeman.Rasjid 2001. Fiqh Islam. Bandung: Sinar Baru Algensindo.

Rahyubi, Heri, 2014. Teory-Teory Belajar Dan Aplikasi Pembelajaran Motorik. Bandung, 